JUAN FRANCISCO COLOMA, Ph.D. ${ }^{1}$

(Corresponding author)

E-mail: jfcoloma@unex.es

MARTA GARCIA, Ph.D. ${ }^{1}$

E-mail: martagg@unex.es

RAÚL GUZMÁN, Ph.D. ${ }^{1}$

E-mail: rguzman@unex.es

${ }^{1}$ Department of Construction

Betancourt Research Group

University of Extremadura

Avda. de la Universidad s/n, 10003 Cáceres, Spain
Traffic Planning

Review

Submitted: 21 Sep. 2017

Accepted: 5 Feb. 2018

\title{
EFFECTS OF BYPASS IN SMALL AND NON-CONGESTED CITIES: A CASE STUDY OF THE CITY OF BADAJOZ
}

\begin{abstract}
Small cities with less than 200,000 inhabitants do not usually suffer from chronic congestion problems. However, private vehicles are used excessively, making it necessary to implement measures to encourage further use of public transport and pedestrian mobility to make it more sustain able. Bypasses improve level of service (LOS) by removing cars from the city center, leading to significant reductions in overall travel time. Most studies so far have been conducted in large cities suffering chronic congestion problems, so the aim of this research is to analyze the effects of bypasses in small and non-congested cities through the construction of a traffic model in Badajoz (Spain), starting with the allocation of the origin-destination travel matrix derived from surveys and traffic counts conducted at the southern and eastern accesses. The traffic model describes the mobility in potentially-capturable future southern traffic relationships and allows insights into different alternatives in the construction of a new high LOS road. This research concludes that small cities with no chronic congestion problems should plan bypasses as close as possible to the city, since they are the most economical, produce greater traffic capture, greater time savings, and eliminate the largest number of $\mathrm{CO}_{2}$ emissions from the urban center. The more distant alternatives have a higher LOS, however, these are longer and more expensive solutions that also capture less traffic and thus eliminate less $\mathrm{CO}_{2}$ emissions.
\end{abstract}

\section{KEY WORDS}

transport planning; traffic model; origin-destination matrix; Badajoz;

\section{INTRODUCTION}

Greenhouse gas (GHG) emissions and overconsumption of energy resources represent a global problem, which is related both to their causes and consequences [1].

The transportation sector is one of the largest emitters of GHG [2] despite advances in the field of engine technology. This sector accounted for $26 \%$ of global energy consumption in 2010, and transportation energy use is expected to increase by $1.1 \%$ every year until 2040 [3].

Small cities with less than 200,000 inhabitants do not usually suffer from chronic congestion problems. However, private vehicles are used excessively, making it necessary to implement measures to encourage further use of public transport and pedestrian mobility for greater sustainability. Bypasses improve LOS by removing cars from the city center, leading to significant reductions in overall travel time [4].

Evaluation of bypass influence on reducing air pollution has been carried out in numerous studies [5-7]. However, such studies are always carried out for large cities with congestion problems. It is therefore necessary to investigate whether such actions are also valid for smaller cities and to learn how to improve mobility and reduce emissions in urban centers $[8,9]$.

The city of Badajoz currently has a population of approximately 150,000 inhabitants. It is the main urban center in Extremadura, and it has the characteristics of any European average city. Moreover, its geographical location makes it even more privileged for being a border city and the barycenter of three huge European cities: Lisbon, Madrid, and Seville. [10]

The road network of Badajoz has a radial infrastructure composed by an ensemble of roads which leave the city and whose axes serve as support for its own growth. The main road (BA-20) passing through Badajoz registers about 132,000 trips daily. Here arises the need for building a new southern bypass, which would allow cars coming from other towns to link with the motorway Madrid-Badajoz and the rest of the communication roads without entering the city center of Badajoz. The so-called Southern Bypass (Ronda Sur) will become an authentic variant of roads which will receive the status of fast track and, together with the motorway of Extremadura, will surround the whole city center of Badajoz [11]. 


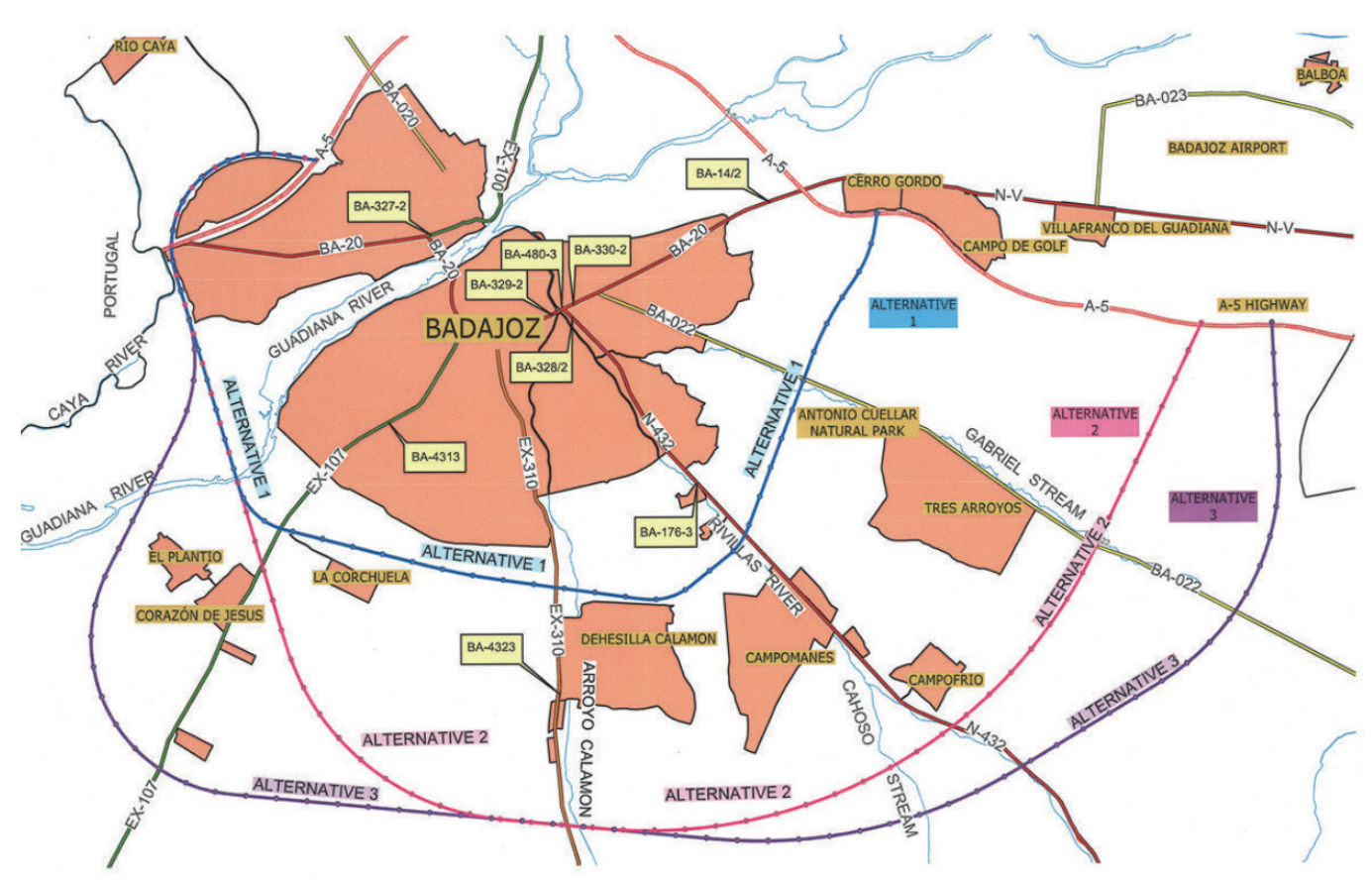

Figure 1 - Alternatives and counting stations studied at the Southern Bypass of Badajoz

Between 2010 and 2014 an informative study about the Southern Bypass in Badajoz was written, detailing its possible corridors and planning alternatives of the future variant [12] (Figure 1).

Alternative 1 is approximately 22 kilometers long. This alternative is the shortest and the closest to the city. It is also the one that was contemplated in the urban planning of Badajoz. Alternative 2 is approximately 30 kilometers long. It runs behind most of the secondary cores making the new route only pick up long distance traffic that does not need to cross the city. Alternative 3 has is approximately 36 kilometers long. It picks up some secondary cores that do not reach alternative 2, and it is outside the protected areas of oak forest that are occupied by this alternative.

On October 6, 2014, the Government of Extremadura approved the informative study [13] selecting the alternative 1 . The three alternatives provide a solution to the problems of mobility and pollution existing in the urban center. The selected alternative is the most economical, since it is shorter; however, it is unknown if it is the alternative that captures more traffic and if it is the one that obtains greater savings in terms of travel times and $\mathrm{CO}_{2}$ emissions.

The aim of this research is to analyze the effects of bypasses in small and non-congested cities by developing a traffic model for the city of Badajoz which provides insight into different alternatives' behavior in the construction of a new high LOS road. The model is able to select the one which captures more traffic and produces bigger savings in travel time and $\mathrm{CO}_{2}$ emissions, meaning the one which produces better socioeconomic improvement.

\section{METHODOLOGY}

Traffic study for the planning of new urban roads is an especially significant chapter, not only because it is necessary to know the number of vehicles that will circulate in each of the planned alternatives, but also as indispensable data to estimate their social and economic profitability [14]. It is very important to have the simulation model and allocation from the very beginning of the planning to have knowledge of the traffic that each of the corridors will capture, creating an extremely valuable auxiliary element for the selection process.

The construction of a traffic model in Badajoz will be done by assigning an origin-destination travel matrix derived from surveys and counts done at the southern and eastern accesses of Badajoz [15, 16]. The traffic model describes the mobility in potentially capturable relationships for a future southern bypass and allows the calculation of savings in traveled distance and travel times in relation to the current situation [17].

Activities done in the construction of the traffic model of the city of Badajoz are enumerated below:

1) Traffic characterization of the Southern Bypass of Badajoz starting from the data from the traffic maps of the Ministry of Development and Government of Extremadura $[18,19]$. 
2) Collection and analysis of the information on mobility and traffic at the accesses to Badajoz from south and east, through surveys and counts.

3) Estimation of the average daily traffic (ADT) in specific count locations.

4) Utilization of the surveys carried out and collection of results.

5) Estimation of the origin-destination matrix in the studied area from the surveys done.

6) Creation of the traffic model of Badajoz and its road network.

7) Estimation of the traffic captured by each alternative selected for the Southern Bypass of Badajoz. This estimation derives from the assigning of the traveling matrix to each network, including the alternative which is the object of the evaluation.

8) Estimation of the traffic collected (vehicles-km) and travel time savings (vehicles-hour) for each selected alternative.

9) Estimation of $\mathrm{CO}_{2}$ emissions saved from the urban center.

\subsection{Collecting of information about mobility and traffic}

Collection of information about transportation demand aims to determine how people move within the study area, in order to estimate mobility. The basic data collected for each trip will in this case be the means of transport, the origin of the trip, and its destination.

Willumsen [20] and, most recently, Bernardín et al. [21] recommend generating traffic models from surveys and counts in situ because they are not highly expensive and constitute the most truthful starting point there can be. Therefore, the basic form of collecting data has been through origin-destination surveys done

in the city center of Badajoz. As a complement, information about network usage was collected through counts with the aim of learning how supply works, and giving information for the utilization of the surveys.

A total of 3,759 origin-destination surveys took place at the southern accesses of Badajoz which currently channel the potentially-capturable traffic for the future Southern Bypass.

\section{Selection of locations for surveys and counts}

Places with traffic lights were selected so that the survey could take place while every vehicle was stopped. After obtaining a view of the study area, five survey points were selected (Figure 2) and are listed as follows:

P1 EX-107. Avenue Luis Movilla Montero (Neighborhood of Llera).

P2 EX-310. Avenue Damián Téllez Lafuente crossing with BA-20.

P3 N-432 crossing with Avda. Luis de Góngora.

P4 BA-022 (Corte de Peleas road) crossing with BA-20.

P5 BA-20 (Avenue Juan Sebastián el Cano) crossing with BA-022.

Origin-destination surveys

3,759 surveys took place with the following distribution per survey positions:

Position 1

Position 2

Position 3

3.1. Straight movement

3.2. Turn in Luis de Góngora

Position 4

Position 5

616 surveys

604 surveys

705 surveys

324 surveys

381 surveys

495 surveys

634 surveys

The origin-destination surveys were taken on Wednesday, October 5, 2011, from 8 a.m. until 8 p.m., using the questionnaire in Figure 3.

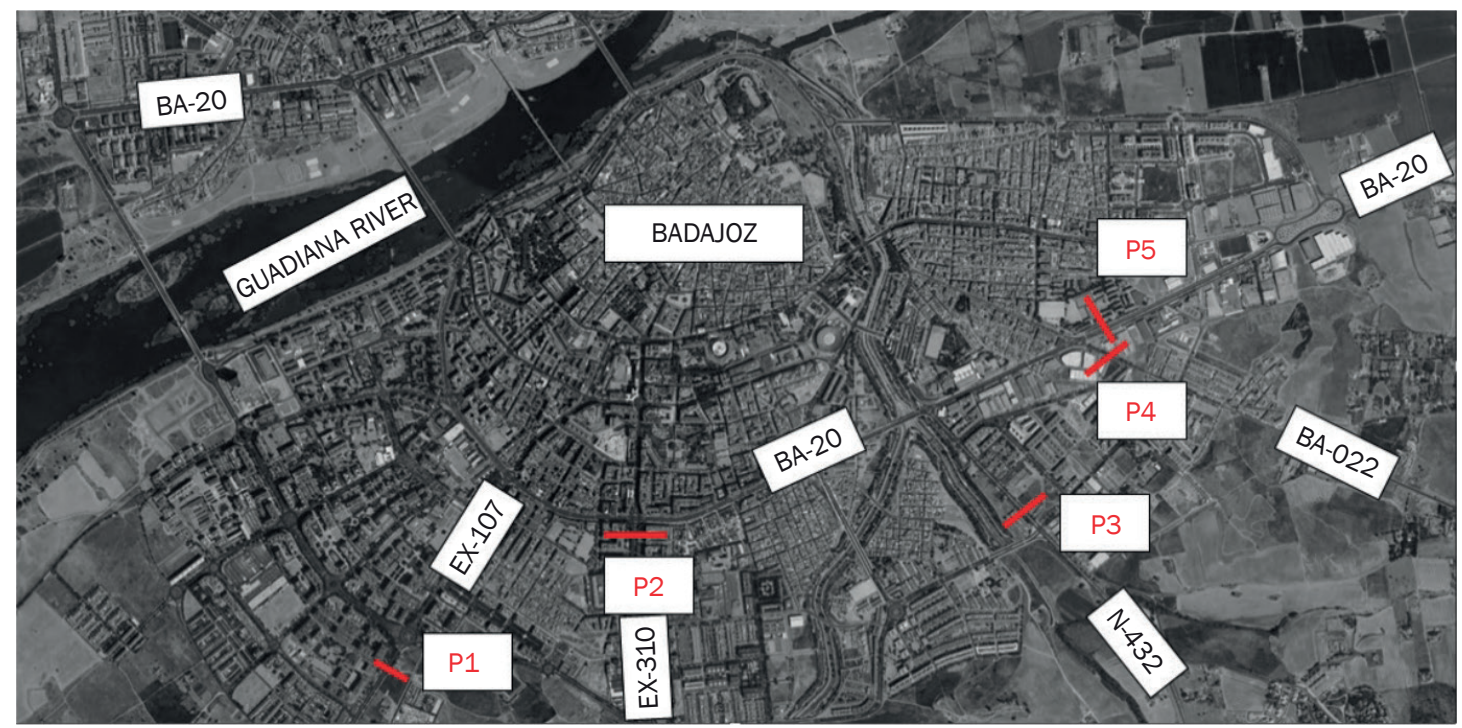

Figure 2 - Survey points positions 
TRAFFIC STUDY OF THE SOUTH BYPASS OF BADAJOZ ORIGIN-DESTINATION SURVEY

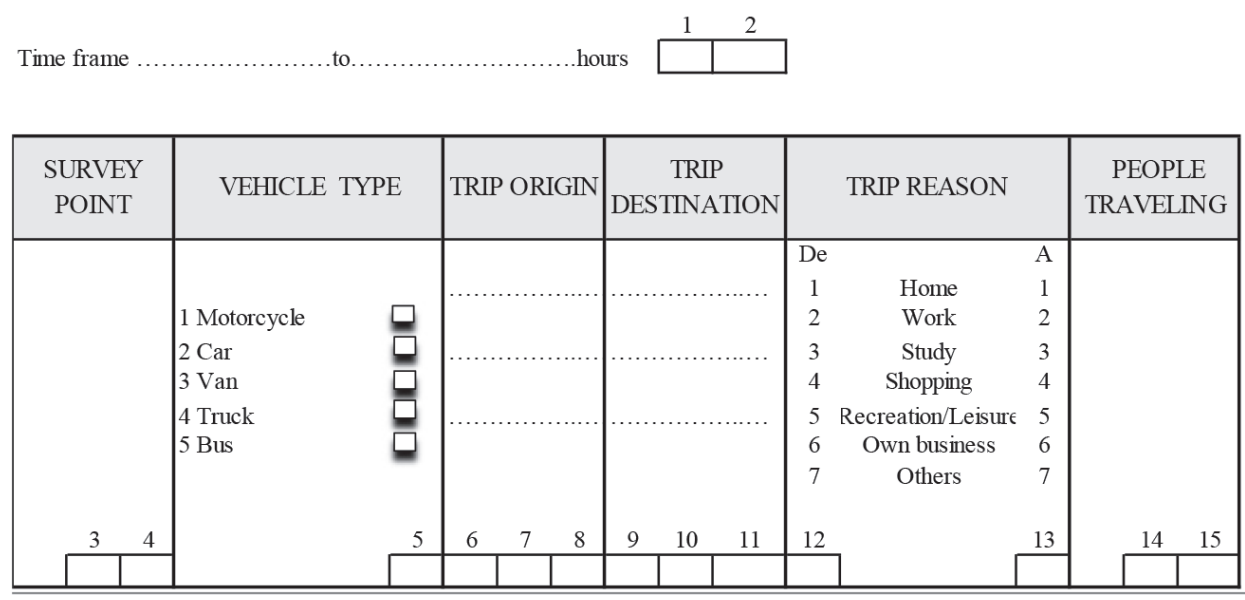

Figure 3 - Survey template used [22]

Table 1 - Result of the vehicle count in the selected control locations

\begin{tabular}{|c|c|c|c|c|c|c|}
\hline \multicolumn{7}{|c|}{ Vehicle count for the traffic study of the Southern Bypass of Badajoz } \\
\hline \multirow[b]{2}{*}{ Time frame } & \multirow{2}{*}{$\begin{array}{c}\begin{array}{c}\text { Luis Movilla } \\
\text { Montero } \\
\text { Avenue }\end{array} \\
\text { Position } 1\end{array}$} & \multirow{2}{*}{$\begin{array}{c}\begin{array}{c}\text { Damián Téllez } \\
\text { Lafuente } \\
\text { Avenue }\end{array} \\
\text { Position } 2\end{array}$} & \multicolumn{2}{|c|}{$\begin{array}{l}\text { Sevilla Road } \\
\text { N-432 }\end{array}$} & \multirow{2}{*}{$\begin{array}{c}\begin{array}{c}\text { Corte de } \\
\text { Peleas Road }\end{array} \\
\text { Position } 4\end{array}$} & \multirow{2}{*}{$\begin{array}{c}\text { BA-20 } \\
\text { J.S. El Cano } \\
\text { Position } 5\end{array}$} \\
\hline & & & $\begin{array}{c}\text { Position } 3.1 \\
\text { (Straight) } \\
\end{array}$ & $\begin{array}{l}\text { Position } 3.2 \\
\text { (L. Góngora) } \\
\end{array}$ & & \\
\hline 06:01 a 07:00 & 148 & 161 & 50 & 19 & 52 & 83 \\
\hline 07:01 a 08:00 & 516 & 579 & 204 & 145 & 268 & 553 \\
\hline 08:01 a 09:00 & 746 & 770 & 320 & 228 & 397 & 950 \\
\hline 09:01 a 10:00 & 517 & 558 & 285 & 217 & 296 & 836 \\
\hline 10:01 a 11:00 & 464 & 484 & 292 & 186 & 260 & 782 \\
\hline $11: 01$ a $12: 00$ & 545 & 585 & 283 & 192 & 295 & 768 \\
\hline $12: 01$ a 13:00 & 810 & 623 & 303 & 222 & 232 & 753 \\
\hline 13:01 a 14:00 & 841 & 809 & 348 & 215 & 314 & 874 \\
\hline $14: 01$ a $15: 00$ & 428 & 642 & 190 & 165 & 251 & 984 \\
\hline $15: 01$ a $16: 00$ & 608 & 574 & 217 & 142 & 200 & 852 \\
\hline $16: 01$ a 17:00 & 628 & 544 & 295 & 190 & 236 & 729 \\
\hline 17:01 a 18:00 & 656 & 758 & 300 & 280 & 294 & 740 \\
\hline 18:01 a. $19: 00$ & 686 & 642 & 267 & 178 & 362 & 908 \\
\hline 19:01 a 20:00 & 749 & 663 & 351 & 249 & 387 & 1,103 \\
\hline 20:01 a 21:00 & 963 & 673 & 329 & 235 & 321 & 933 \\
\hline 21:01 a 22:00 & 951 & 518 & 205 & 115 & 147 & 524 \\
\hline Total vehicles counted & 10,256 & 9,583 & 4,239 & 2,978 & 4,312 & 12,372 \\
\hline
\end{tabular}

\section{Counts}

Simultaneously with the surveys, a 16-hour vehicle count (from 6:00 to 22:00) of the surveyed traffic was carried out. The results of the vehicle count are shown in Table 1.

\subsection{Utilization of the surveys}

The basic aim of the surveys was to obtain the expressive mobility matrix of the transport demand between each pair of zones considered. In survey utilization, three basic activities can be pointed out: 
- Coding of surveys. It consists on translating numeric data and collected information in the survey, the origin-destination coding being of particular interest because it supports the division of the studied area into zones and the defined area codes [23, 24].

- Calculation of the expansion coefficients. It is about establishing the necessary conversion coefficient to extrapolate the results of the surveys from a part of the vehicles and users (sample) to the total of vehicles and users (universe).

- Collecting of the origin-destination matrix. After coding the surveys, the result is the origin-destination travel matrix which expresses the mobility flow of vehicles classified by type of vehicle and it refers to the universe of vehicles passing through the positions of the survey.

\section{Calculation of the expansion coefficient}

Expansion coefficient represents the converting coefficient from the surveyed users (sample) to the total of users (universe) [25]. This expansion coefficient has been calculated for each position of the survey and hour period through the following Equation 1.

$E C_{i, h}=\frac{V C_{i, h}}{V S_{i, h}}$

where: $E C_{i, h}$ is the expansion coefficient of the surveys in position $i$ during time period $h ; V C_{i, h}$ are the vehicles counted in position $i$ during time period $h ; V S_{i, h}$ are the vehicles surveyed in position $i$ during time period $h$.

The resulting expansion coefficients in survey positions are:

Position $1 \quad 1.2594$

Position 21.0996

Position 3.1. 1.1437

Position 3.2. 1.1254

Position $4 \quad 1.1161$

Position $5 \quad 1.2025$

Construction of the origin-destination travel matrix in the study area for 2014

The origin-destination travel matrix was obtained through the following process:

1) Travel matrix expansion from the surveys to 2014 ADT estimated. Expansion coefficients described previously were used.

2) Matrices correction, checking each origin-destination relationship, and adapting the origin and/or destination zones to the survey positions.

3) Travel matrix in the study area captured in a single direction in the positions of the survey.

4) Duplication of the connecting trips in the western area of study captured in a single direction in the survey positions.

5) Travel matrix rezoning, making it a simplified 78 zone area. The selected zones for this simplification were: Zones 1 to 65 - considered for this count in the municipality of Badajoz, Zones 66 and 67 - Talavera La Real, Zones 68 to 78 - different accesses to the city of Badajoz.

\section{RESULTS}

\subsection{Traffic model in the road network of Badajoz}

Network assigning models simulate the behavior of a transportation network through the collecting of the traffic loads derived from the travel matrix. This matrix represents the mobility in the study area for a determined year. The traffic which the Southern Bypass will capture is obtained by assigning the 2014 travel matrix to the defined road network, including the 3 bypass alternatives for the future situation.

To be able to make a model of the network, a drawing which guaranteed all the possible coherent itineraries between each pair of centroids (representation of the origin and destination network of a journey) was made [26]. The road network of the study area for 2014 was modeled defining the following parameters for each route: origin knot, destination knot, distance between knots, type of arc, average travel distances, and circulation directions.

8 types of arcs and the following average travel velocities were considered: (1) roads in the city center $(15-20 \mathrm{~km} / \mathrm{h}),(2)$ roads in the surroundings (20-35 $\mathrm{km} / \mathrm{h}),(3)$ urban motorway $(60-80 \mathrm{~km} / \mathrm{h})$, (4) suburban motorway (100-110 km/h), (5) urban road (40-50 $\mathrm{km} / \mathrm{h}),(6)$ suburban road $(50-75 \mathrm{~km} / \mathrm{h}),(7)$ centroid access (15 km/h), (8) bypass ( $80 \mathrm{~km} / \mathrm{h})$.

Cascetta and Ruso [27], and later Russo and Vitetta [28] and Shrewsbury [29], expressed the necessity of adjusting the network (calibration) by checking that the itineraries which allow establishing the modeled network correspond with the reality. This calibration is made calculating the minimum-cost paths (time and distance) from a group of selected centroids and checking them against the real ones used by the users in 2014.

Once it was modeled for the year 2014, the future model was made with the commissioning of the Southern Bypass. It was necessary to include the new arcs which describe each of its 3 alternatives. In Figure 4 there is a representation of the road network in 2014, and in Figure 5 there is a representation of the future network with the commissioning of the Southern Bypass.

\subsection{Traffic captured by Southern Bypass alternatives}

The traffic captured by each of the Southern Bypass alternatives was estimated by assigning the origin-destination travel matrix to the future route network which 


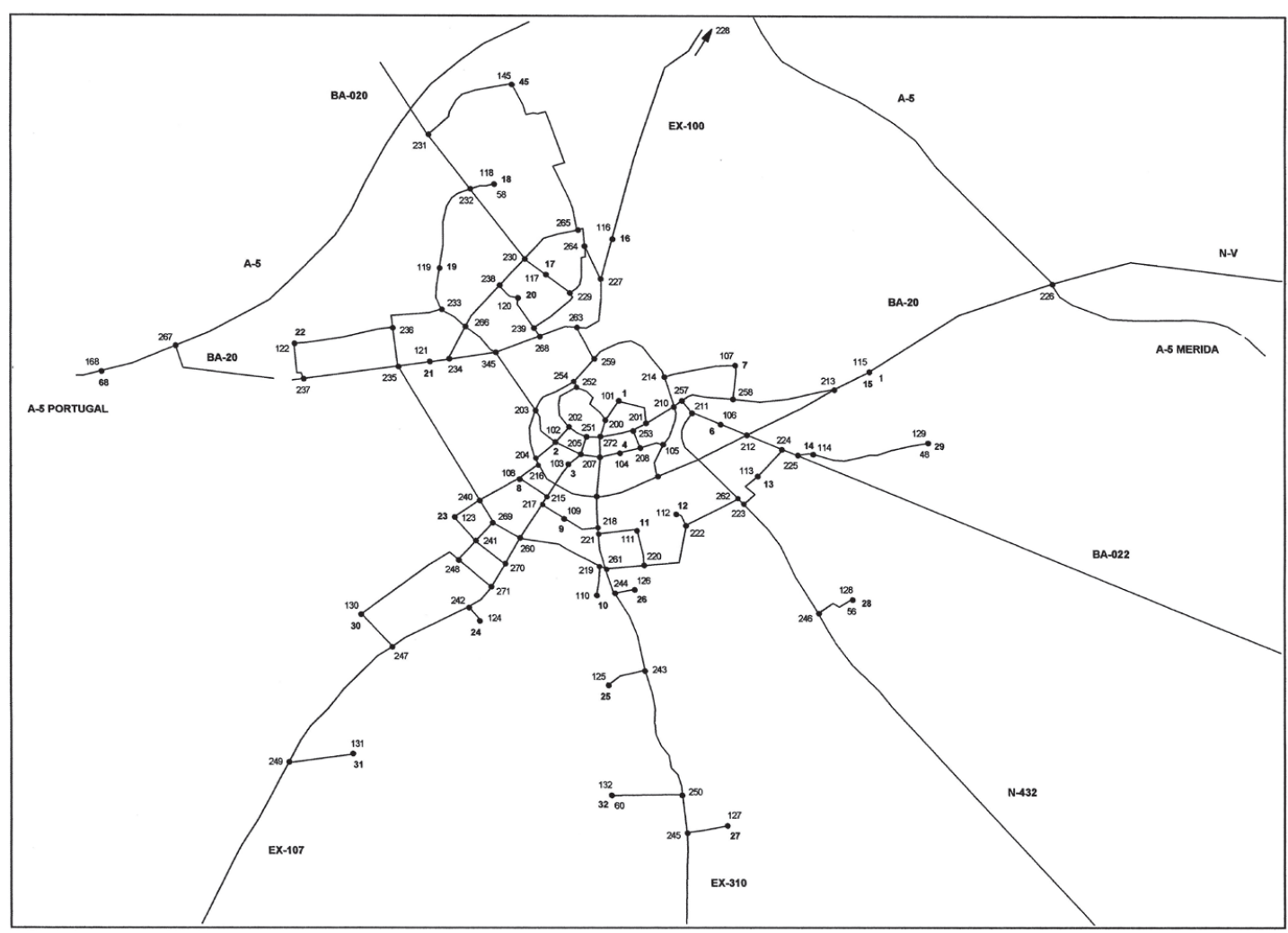

Figure 4 - Traffic model of Badajoz city for the year 2014 [veh/h]

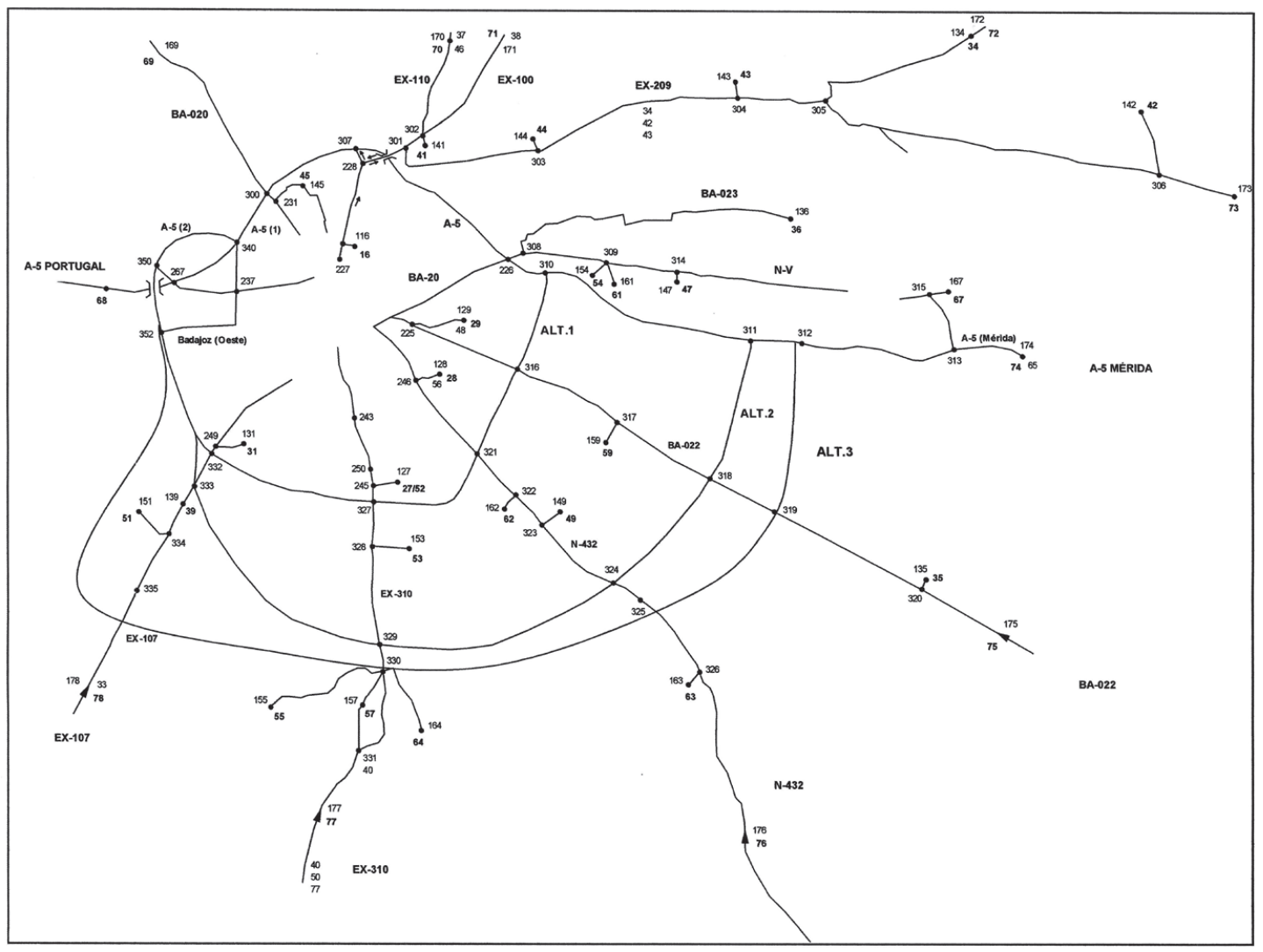

Figure 5 - Traffic model in Badajoz city with the commissioning of Southern Bypass [veh/h] 
includes each of the 3 Southern Bypass alternatives. There are several methods to assign this, such as the "all or nothing" or the stochastic method. The stochastic methods of traffic assignment reveal the variability of the users, their perception of the costs, and the way to simultaneously minimize the distance and the travel time, therefore, the general costs. These methods could be based on a simulation as in Burrell [30], or they could be proportional. The proportional methods are based on a network load algorithm and distribute the trips which arrive to the node among the other entire possible exit knots, contrary to the "all or nothing" assigning method, which assigns all trips to an individual exit node.

In this research, the traffic assigning was carried out using a stochastic proportional method of assigning alternative routes: the Dial method [31]. In this method, two or more alternative routes are assigned between each pair of zones, dividing the existing flow between those itineraries, considering the generalized minimum cost (distance+time) and the generalized cost for each of the itineraries. According to the Dial method, the trips in each origin-destination relationship are divided among the different itineraries through a logit type division model. In Equation 2, the simplest case of a logit model is represented, which is the one that only considers two different options to choose from, considering for each trip the characteristics of the generalized cost. In this case, a similar one to the Ortuzar model is used [32] with the same primary and secondary modal split dispersion parameters $\left(\kappa_{1}=\kappa_{2}\right)$, which makes it a simple multinomial logit model (MNL) [33, 34].

$$
p(1)=\frac{1}{1+e^{-\kappa\left(C_{1}-C_{2}\right)}}
$$

where: $p(1)$ is the probability of the traveler using itinerary number $1 ; C_{1}$ and $C_{2}$ are the generalized costs of itinerary numbers 1 and 2 , respectively; $\alpha$ is the dispersion parameter. Measuring the model from the known values through the surveys and counts, the value of $\Lambda=0.10$ has been adjusted.

$C_{1}-C_{2}=0$ indicates that the utility of both options is the same, and the election probability of option 1 is 0.5 , which corresponds to the situation of indifference against option 2 . When the difference $C_{1}-C_{2}$ acquires increasing positive values, the utility of option 1 increases even more compared to the growth of option 2 , and the probability of choosing option 1 tends to unity. When the difference $C_{1}-C_{2}$ acquires negative values indicating option 2 has better utility than number 1 , the probability of choosing option 1 decreases, getting close to zero. The results of these estimations are presented for each of the Badajoz Southern Bypass alternatives in Table 2.

\subsection{Traffic collected and travel time saving}

During the process of assigning, the numbers of vehicles per kilometer (traffic) and vehicles per hour (travel time) used for the movements through the three Southern Bypass alternatives included in the travel matrix were obtained as complementary information. The difference in traffic captured and time saving is obtained when comparing the parameters of each alternative with those from the network in 2014.

It is important to highlight that the socio-economically most feasible alternative will be the one which obtains the highest number of vehicles-km and the least vehicles-hour, since it will be the one that captures more traffic and produces greater time savings. The results are presented in Table 3.

Alternative 1 is the one that collects the most traffic (2.25\% more than in 2014); it is also the one that saves more travel time, reducing the situation of 2014 by $1.82 \%$.

Table 2 - Number of vehicles per hour captured by the Southern Bypass alternatives

\begin{tabular}{|c|c|c|c|c|c|c|c|c|c|c|}
\hline \multicolumn{11}{|c|}{ Alternative 1} \\
\hline A-5/ PORTUGAL & 928 & EX-107 & 2,163 & EX-310 & 5,336 & $\mathrm{~N}-432$ & 2,094 & BA-903 & 2,166 & A-5/ MÉRIDA \\
\hline \multicolumn{11}{|c|}{ Alternative 2} \\
\hline A-5/ PORTUGAL & 843 & EX-107 & 1,137 & EX-310 & 1,803 & $\mathrm{~N}-432$ & 732 & BA-903 & 813 & A-5/ MÉRIDA \\
\hline \multicolumn{11}{|c|}{ Alternative 3} \\
\hline A-5/ PORTUGAL & 463 & EX-107 & 601 & EX-310 & 1,568 & $\mathrm{~N}-432$ & 701 & BA-903 & 772 & A-5/ MÉRIDA \\
\hline
\end{tabular}

Table 3 - Differences in vehicles-km (traffic) and vehicles-hour (travel time) between each Southern Bypass alternative and comparison with the network in 2014

\begin{tabular}{||l|c|c|c|c|c|c|c|c|c|c||}
\hline \multirow{2}{*}{ Parameters } & \multirow{2}{*}{ Year 2014 } & \multicolumn{3}{|c|}{ ALT-1 } & \multicolumn{3}{|c|}{ ALT-2 } & \multicolumn{3}{c||}{ ALT-3 } \\
\cline { 3 - 12 } & & Value & Dif. & $\%$ & Value & Dif. & $\%$ & Value & Dif. & $\%$ \\
\hline \hline Vehicle-km & 550,926 & 563,244 & $+12,418$ & +2.25 & 557,395 & $+6,470$ & +1.16 & 554,147 & $+3,221$ & +0.58 \\
\hline Vehicle-h & 11,226 & 11,022 & -204 & -1.82 & 11,141 & -85 & -0.76 & 11,134 & -92 & +0.82 \\
\hline
\end{tabular}




\section{$3.4 \mathrm{CO}_{2}$ emissions}

The measurements were made with vehicles of different typology (Fiat 500 1,200 cc gasoline and Opel Astra 1,600 cc diesel) to analyze the difference of impacts between types and to be able to apply them to the fleet of the city of Badajoz (Table 4). The results are shown in Table 5.

Alternative 1 is the one that captures more traffic and therefore eliminates the largest number of vehicles from the city center and the highest amount of $\mathrm{CO}_{2}$ emissions.

\section{CONCLUSIONS AND DISCUSSION}

Planning new high-capacity roads in small cities, whether they are collective-distributor routes or single variants, requires an effective traffic model which is able to provide insight into the mobility of the current city and simulate the future behavior with the commissioning of the new route. Designing an adequate traffic model provides information about the behavior of different potential alternatives in the construction of a new high-capacity route, and, in this way, facilitates selecting the one which captures more traffic and produces bigger savings in travel times, meaning the highest socioeconomic feasibility.

This research analyzes the effects of bypasses in small and non-congested cities by developing a traffic model in Badajoz, starting from the assigning of the origin-destination travel matrix derived from the surveys and counts made at the southern and eastern accesses of Badajoz. The traffic model describes the mobility in potentially-capturable relationships for the

Table 4 - Technical information of the vehicles used in this research [35, 36]

\begin{tabular}{||l|c|c||}
\hline \multicolumn{1}{|c|}{ Features } & Astra values & Fiat values \\
\hline \hline Name & Opel Astra 1.6 CDTI 110 cv & Fiat 500 1.2 69 CV \\
\hline Commercial section & Saloon & Gasoline \\
\hline Engine type & Diesel & 1242 \\
\hline Cylinder capacity $\left(\mathrm{cm}^{3}\right)$ & 1598 & Manual \\
\hline Gear shift type & Manual & 1305 \\
\hline Maximum permitted mass & 2010 & 93,75 \\
\hline Power CV & 110,05 & $3546 \times 1627 \times 1488$ \\
\hline Dimensions $($ WxDxH) $[\mathrm{mm}]$ & $4419 \times 1814 \times 1510$ & 4 \\
\hline Maximum number of seats & 5 & 4,9 \\
\hline Average fuel consumption & 4,1 & 115 \\
\hline Emissions [gCO2/km] & 109 & 2,347 \\
\hline Emissions $[\mathrm{gCO} / \mathrm{l}$ ] & 2,658 & D \\
\hline Classification by relative consumption & A & \\
\hline
\end{tabular}

Table 5 - Vehicles and $\mathrm{CO}_{2}$ emissions in the Southern Bypass alternatives saved from the urban center

\begin{tabular}{|c|c|c|c|c|c|c|}
\hline \multicolumn{7}{|c|}{ Alternative 1} \\
\hline & A-5/ PORTUGAL-EX-107 & EX-310 & $\mathrm{N}-432$ & BA-903 & A-5/MERIDA & Total \\
\hline Vehicles & 928.0 & $2,163.0$ & $5,336.0$ & $2,094.0$ & $2,166.0$ & $12,687.0$ \\
\hline Length [km] & 8.3 & 4.6 & 3.5 & 2.6 & 3.0 & 22.0 \\
\hline Emissions $\left[\mathrm{kgCO}_{2}\right]$ & 862.7 & $1,114.4$ & $2,091.8$ & 609.8 & 727.8 & $5,406.5$ \\
\hline \multicolumn{7}{|c|}{ Alternative 2} \\
\hline & A-5/ PORTUGAL-EX-107 & EX-310 & $\mathrm{N}-432$ & BA-903 & A-5/MERIDA & Total \\
\hline Vehicles & 843.0 & $1,137.0$ & $1,803.0$ & 732.0 & 813.0 & $5,328.0$ \\
\hline Length [km] & 8.7 & 7.0 & 6.7 & 3.8 & 4.0 & 30.2 \\
\hline Emissions $\left[\mathrm{kgCO}_{2}\right]$ & 821.5 & 891.5 & $1,353.0$ & 311.6 & 364.3 & $3,741.9$ \\
\hline \multicolumn{7}{|c|}{ Alternative 3} \\
\hline & A-5/ PORTUGAL-EX-107 & EX-310 & $\mathrm{N}-432$ & BA-903 & A-5/MERIDA & Total \\
\hline Vehicles & 463.0 & 601.0 & $1,568.0$ & 701.0 & 772.0 & $4,105.0$ \\
\hline Length [km] & 12.5 & 6.7 & 7.6 & 4.4 & 4.8 & 36.0 \\
\hline Emissions $\left[\mathrm{kgCO}_{2}\right]$ & 648.2 & 451.0 & $1,334.7$ & 345.5 & 415.1 & $3,194.5$ \\
\hline
\end{tabular}


future southern variant and allows calculation of savings in travel distances and times in relation to the situation in 2014.

Analyzing the results in Table 3, one might conclude that, from the point of view of the traffic, alternative 1 , which is the nearest to the city center, is preferred to alternatives 2 and 3 since it is the alternative with the highest number of vehicles-km (2.25\% more traffic) and the one with the lowest number of vehicles-hour (1.82\% less travel time). Alternative 1 is also the one that produces greater savings of $\mathrm{CO}_{2}$ emissions from the city center (Table 5), reaching values that approximate $80 \%$ of the sum of the other two alternatives.

In terms of evaluating the performance of the method chosen, it is necessary to note that the "all or nothing" assigning methods and the stochastic methods do not take into account the capacities of the roads, assigning higher amounts of traffic to specific stretches which might not have that required capacity. The assigning method per stretches with capacity restriction takes this issue into account $[37,38]$. However, due to the fact that Badajoz is not a city with severe traffic jam problems, the use of models which contemplate the restriction of capacity is not necessary, and the use of simpler methods which do not take this into account seems more adequate, such as the Dial method used in this research.

The chosen method should be used only in small cities which have no traffic jam problems. This is because in cities with traffic jam problems the application of the expansion coefficient constant to obtain the O/D matrix would produce a lot of errors [39, 40]. Moreover, as shown previously, there is the possibility of errors in traffic assignment considering the lack of capacity on the roads.

It is also necessary to emphasize that there are authors who use zoning-distributing models of gravitational demand, which are more economical since they do not require surveys and have proven to be sufficiently precise [41-45].

All these determinants make each assigning method suitable for a specific field of application in relation to the characteristics of the assigned network and the problem to analyze and evaluate. In interurban networks, the "all or nothing" and stochastic methods are usually used (Dial method). In urban networks, the capacity restricting methods per stretch are used and, to a lesser extent, the Burrel method. In interurban corridors, with alternative itineraries (toll motorway or important variants), the delivery curves are used [46, 47]. This method consists on supposing that between each pair of zones there are at least two alternative ways with their own characteristics of time, distance, and level of service. The journeys by the first or the second itinerary are distributed taking into account the already-established delivery curves, which define the percentage by either itinerary according to time saved, distance saved, the travel time ratio, traveled distance ratio, etc. Due to the nature of the variant of the Badajoz Southern Bypass, it could be interesting as a future research detour to analyze an alternative model of assignment using this method and compare it to the results obtained in this research.

These results point to certain policy recommendations for small cities to develop bypasses as close as possible to the city, as it has been demonstrated in this research that it is the alternative that produces greater traffic capture, greater time savings and eliminates the largest number of $\mathrm{CO}_{2}$ emissions from the urban center. It is also the alternative with the shortest route, therefore the most economical.

\section{ACKNOWLEDGEMENT}

The authors would like to acknowledge the Government of Extremadura (Spain) for funding the Informative Study of Badajoz Southern Bypass (Ronda Sur de Badajoz), under which this research has taken place.

JUAN FRANCISCO COLOMA, Profesor Ayudante ${ }^{1}$

E-mail: jfcoloma@unex.es

MARTA GARCIA, Profesora Titular de Escuela Universitaria ${ }^{1}$

E-mail: martagg@unex.es

RAUL GUZMAN, Profesor Asociado ${ }^{1}$

E-mail: rguzman@unex.es

${ }^{1}$ Departamento de Construcción,

Grupo de Investigación Betancourt

Universidad de Extremadura

Avda. de la Universidad s/n, 10003 Cáceres, España

\section{EFECTOS DE BYPASS EN CIUDADES PEQUEÑAS Y NO CONGESTIONADAS: ESTUDIO DEL CASO DE LA CIUDAD DE BADAJOZ}

\section{RESUMEN}

Las ciudades pequeñas con menos de 200,000 habitantes no suelen sufrir problemas crónicos de congestión. Sin embargo, el vehículo privado se usa excesivamente, por lo que es necesario implementar medidas para fomentar un mayor uso del transporte público y desplazamientos peatonales para hacerlo más sostenible. Los bypass mejoran el nivel de servicio (LOS) mediante la eliminación de los automóviles del centro de la ciudad, lo que lleva a reducciones significativas en el tiempo total de viaje. La mayoría de los estudios hasta ahora se han realizado en grandes ciudades con problemas crónicos de congestión, por lo que el objetivo de esta investigación es analizar los efectos de los bypass en ciudades pequeñas y no congestionadas a través de la construcción de un modelo de tráfico en Badajoz (España) comenzando con la asignación de la matriz de viajes de origen-destino derivada de las encuestas y recuentos de tráfico realizados en los accesos sur y este. El modelo de tráfico describe la movilidad en futuras relaciones de tráfico en el sur potencialmente capturables y permite conocer diferentes comportamientos alternativos en la construcción de una nueva carretera de alta LOS. Esta investigación concluye que las ciudades pequeñas sin problemas de congestión 
crónica deben planear desvíos lo más cerca posible de la ciudad, ya que son los más económicos, producen mayor captura de tráfico, mayor ahorro de tiempo y eliminan la mayor cantidad de emisiones de $\mathrm{CO}_{2}$ del centro urbano. Las alternativas más lejanas tienen un LOS más alto, sin embargo, estas son soluciones más largas y más caras, capturan menos tráfico y eliminan menos emisiones de $\mathrm{CO}_{2}$.

\section{PALABRAS CLAVE}

planificación del transporte; modelos de tráfico; matrices origen-destino; Badajoz;

\section{REFERENCES}

[1] Ramanathan V, Feng Y. Air pollution, greenhouse gases and climate change: Global and regional perspectives. Atmospheric Environment. 2009;43(1): 37-50. doi:10.1016/j.atmosenv.2008.09.063

[2] Emberger G. Low carbon transport strategy in Europe - A critical review. International Journal of Sustainable Transportation; 2015. doi:10.1080/15568318.2015. 1106246.

[3] Energy Information Administration. International Energy Outlook 2013. No. DOE/EIA-0484(2013). Washington D.C.: U.S. Department of Energy. Available from: https://www.eia.gov/outlooks/ieo/pdf/0484(2013). pdf [Accessed 26 ${ }^{\text {th }}$ June 2017].

[4] Beljatynskij A, Kuzhel N, Prentkovskis O, Bakulich O and Klimenko I. The criteria describing the need for highway reconstruction based on the theory of traffic flows and repay time. Transport. 2009;24(4): 308-317.

[5] Laurinavičius A, Miškinis D, Vaiškūnaitè R, Laurinavičius A. Analysis and evaluation of the effect of studded tyres on road pavement and environment (III). The Baltic Journal of Road and Bridge Engineering. 2010;5(3): 169-176.

[6] Leipus L, Butkus D, Janusevicius T. Research on motor transport produced noise on gravel and asphalt roads/ Autotransporto keliamo triuksmo zvyrkeliuose ir asfaltuotuose keliuose tyrimas/Transporta plusmas radita troksna izpete uz grants un asfalta celiem/Liiklusvahendite tekitatud mura uuring kruus-ja asfaltkatetel. The Baltic Journal of Road and Bridge Engineering. 2010;5(3): 125-125.

[7] Vitkūnas R, Meidutè I. Evaluation of bypass influence on reducing air pollution in Vilnius city. Transport. 2011;26(1): 43-49.

[8] Mitran G, llie S. Method for inventorying CO emissions from road traffic in urban areas through transport modeling. Environmental Engineering and Management Journal. 2014;13(8):1945-1956. Available from: http://www.eemj.icpm.tuiasi.ro/pdfs/vol13/ no8/Full/12_172_Mitran_14.pdf [Accessed 15 th Jan 2018].

[9] Shi J, Hu Y, Li S, Li Z, Zhang X, Mao C. Simulation and analysis of road construction traffic flow in urban road networks. Advances in Mechanical Engineering. 2015;7(11): 1-6. doi:10.1177/1687814015618176

[10] Ayuntamiento de Badajoz. Plan General de Ordenación Urbana. 2007. Available from: https://www.aytobadajoz.es/es/ayto/pgm/indice [Accessed 15th Jan 2018].

[11] López F, Del Moral FJ, Valiente P, Bravo JF, Redondo L. Estudio de la movilidad de la ciudad de Badajoz.
Proceedings of the XVI International Congress of Project Engineering. 11-13 Jul 2012, Valencia, Spain. Available from: www.aeipro.com/files/congresos/2012valencia/CIIP12_1260_1271.3799.pdf [Accessed 15 $5^{\text {th }}$ Jan 2018].

[12] Junta de Extremadura. Resolución de 28 de febrero de 2012, de la Dirección General de Infraestructuras y Transporte, por la que se someten a información pública el estudio informativo y el estudio de impacto ambiental de la "Ronda Sur de Badajoz", Diario Oficial de Extremadura (DOE), 12 de marzo de 2012, n 49, p. 4973-4975. Mérida, Spain. Available from: doe.gobex. es/pdfs/doe/2012/490o/12060357.pdf [Accessed $15^{\text {th }}$ Jan 2018].

[13] Junta de Extremadura. Resolución de 6 de octubre de 2014, del Consejero, por la que se aprueba el expediente de información pública y se aprueba definitivamente el estudio informativo de "Ronda Sur de Badajoz", Diario Oficial de Extremadura (DOE), 9 de octubre de 2014, no 195, p. 30.469-30.471. Mérida, Spain. Available from: doe.gobex.es/pdfs/ doe/2014/1950o/14062126.pdf [Accessed 15 ${ }^{\text {th }}$ Jan 2018].

[14] Patriksson M. The traffic assignment Problem: Models \& Methods. New York: Dover Publications, Inc.; 2015. p. 3-6.

[15] Cascetta E. Transportation systems analysis: models and applications. Vol. 29. Springer Science \& Business Media; 2009.

[16] Novačko L, Šimunović Lj, Krasić D. Estimation of Origin-Destination Trip Matrices for Small Cities. Promet - Traffic \& Transportation. 2014;26(5): 419-428.

[17] Ortúzar JD, Willumsen LG. Modelos de transporte. Trans Ibeas-Portilla A, Dell'Olio L. Santander: PUbliCan, Ediciones de la Universidad de Cantabria; 2008. p. 577-604.

[18] Ministerio de Fomento. Datos históricos de tráfico desde 1960 en las estaciones de aforo. Madrid; 2015. Available from: http://www.fomento.es/mfom/ lang_castellano/direcciones_generales/carreteras/ trafico_velocidades/datos_historicos/ [Accessed 21 ${ }^{\text {st }}$ Sep 2017].

[19] Junta de Extremadura. AFOEX. Mérida; 2015. Available from: http://fomento.gobex.es/fomento/live/informacion-ciudadano/carreteras/AforosExtremadura/ AFOEX15.zip [Accessed 27 th Oct 2016].

[20] Willumsen LG. Simplified transport models based on traffic counts. Transportation. 1981;10: 257-278. doi:http://dx.doi.org/10.1007/BF00148462

[21] Bernardin Jr VL, Trevino S, Slater G, Gliebe J. Simultaneous Travel Model Estimation from Survey Data and Traffic Counts. Transportation Research Record: Journal of the Transportation Research Board. 2015;2(2494): 69-76.

[22] Bonsall PW, O'Flaherty CA. Transport planning and traffic engineering. $4^{\text {th }}$ edition. London: Arnold; 1997. p. 232-251.

[23] Viegas JM, Guedes-Gomes F. Codificación de orígenes y destinos de viajes y zonas variables. Ingeniería de Tránsito y Transporte: actas del X Congreso Panamericano. Santander: Ministerio de Fomento; 1998. Cataloged in: WorldCat http://www.worldcat.org/ title/ingenieria-de-transito-y-transporte-actas-del-x- 
congreso-panamericano-santander-21-al-24-de-septiembre-de-1998/oclc/625616084.

[24] Chang KT, Khatib Z, Ou Y. Effects of zoning structure and network detail on traffic demand modeling. Environment and Planning B: Planning and Design. 2002;29(1): 37-52.

[25] Lederman R, Wynter L. Real-time traffic estimation using data expansion. Transport Research B. 2011;45: 1062-1079. doi:http://dx.doi.org/10.1016/ j.trb.2011.05.024

[26] Kang-Tsung C, Zaher K, Yanmei O. Effects of zoning structure and network detail on traffic demand modelling. Environment and Planning B: Planning and Design. 2002;29: 37-52. doi:10.1068/b2742

[27] Cascetta E, Russo F. Calibrating aggregate travel demand models with traffic counts: Estimators and statistical performance. Transportation. 1997;24: 271 293. doi:10.1023/A:1004968411792

[28] Russo F, Vitetta A. Reverse assignment: calibrating link cost functions and updating demand from traffic counts and time measurements. Inverse Problems in Science and Engineering. 2011;19(7): 921-950.

[29] Shrewsbury JS. Calibration of trip distribution by generalised linear models. NZ Transport Agency research report 473, New Zealand, 2012.

[30] Burrell JE. Multiple route assignment and its application to capacity restraint. Proceedings of Fourth International Symposium on the Theory of Traffic Flow. Karlsruhe, Germany; 1968.

[31] Dial RB. A probabilistic multipath traffic assignment model which obviates path enumeration. Transportation Research. 1971;5: 83-111. Cataloged in: WordCat http://worldcat.org/isbn/1840647973

[32] Ortuzar JD. Nested logit models for mixed-mode travel in urban corridors. Transport Research A. 1983;17A(4): 283-299. doi:10.1016/0191-2607(83)90092-4

[33] McFadden D. Conditional Logit Analysis of Qualitative Choice Behavior. In: Zarembka P. (ed.) Frontiers in Econometrics. New York: Academic Press; 1974. p.105-145. Available from: https://eml.berkeley.edu/ reprints/mcfadden/zarembka.pdf

[34] Dissanayake D, Morikawa T. Household travel behavior in developing countries: Nested logit model of vehicle ownership, mode choice, and trip chaining. Transportation Research Record: Journal of the Transportation Research Board. 2002;1805: 45-52.

[35] European Environment Agency. Corinair, 2016. EMEP/
EEA air pollutant emission inventory guidebook 2016. Available from: https://www.eea.europa.eu/publications/emep-eea-guidebook-2016 [Accessed $21^{\text {st }}$ Sep 2017].

[36] Instituto para la Diversificación y ahorro de la Energía. Consumo de Carburante y Emisiones de $\mathrm{CO}_{2}$ en Coches Nuevos; 2017. Available from: http://coches.idae. es/portal/BaseDatos/MarcaModelo.aspx [Accessed $13^{\text {th }}$ June 2017]

[37] Wardrop JG. Some theoretical aspects of road traffic research. Proceedings of the institution of Civil Engineers. Part II. 1952;1: 325-362.

[38] Thamizh-Arasan V, Koshy RZ. Methodology for modeling highly heterogeneous traffic flow. Journal of Transportation Engineering. 2005;131(7): 544-551.

[39] Yang H, Sasaki T, Lida Y, Asakura Y. Estimation of origin-destination matrices from link traffic counts on congested networks. Transport Research Part B. 1992;26 B(6): 417-134. doi:10.1016/0191-2615(92)90008-K

[40] Frederix R, Viti F, Tampère C. Dynamic Origin-Destination estimation in congested networks: theoretical findings and implications in practice. Transportmetrica. 2013;9(6): 494-513.

[41] Robillard P. Estimating the O-D matrix from observed link volumes. Transport Research. 1975;9: 123-128. doi:10.1016/0041-1647(75)90049-0

[42] Horberg P. Estimation of parameters in models for traffic prediction: a non-linear regression approach. Transport Research. 1976;10: 263-265. doi:10.1016/00411647(76)90059-9

[43] Wills MJ. A flexible gravity-opportunities model for trip distribution. Transport research B. 1986;20B(2): 89111. doi:10.1016/0191-2615(86)90001-9

[44] Tamin OZ, Willumsen LG. Transport demand model estimation from traffic counts. Transportation. 1989;16: 3-26. doi:10.1007/BF00223044

[45] Hagen-Zanker A, Jin Y. A new method of adaptive zoning for spatial interaction models. Geographical Analysis. 2012;44(4): 281-301.

[46] McLynn JM, Woronka T. Passenger demand and modal split models. US Northeast Corridor Transportation Project, Report 230, 1969.

[47] Murray-Tuite P, Wolsho, B. Evacuation transportation modeling: An overview of research, development, and practice. Transportation Research Part C: Emerging Technologies. 2013;27: 25-45. 